ISBN 978-93-84468-92-7

International Conference on Issues in Education, Literature, Humanities and Social Sciences

(IELHSS-2017)

Kuala Lumpur (Malaysia) Jan. 4-5, 2017

\title{
Korean Religious Education as an Interreligious Dialogue
}

\author{
Chongsuh Kim \\ Seoul National University, Korea
}

\section{Multi-religious Situation and Religious Conflicts in Korea}

Religion consists of diverse forms, such as native Shamanism (Musok), Confucianism, Taoism, Buddhism, Christianity and new religions in contemporary Korea. According to the Population Census released in 2005 by the Korea National Statistics Office, ${ }^{1}$ there was an estimate of 10,730,000 (22.8\%) Buddhists, 8,620,000 (18.3\%) Protestants, 5,150,000 (10.9\%) Catholics and only 100,000 (0.2\%) Confucianists in Korea. Half of the Korean population consider themselves to be religious and, roughly speaking, one half of the religious people are Christians and the other half, adherents of traditional religions like Buddhism and Confucianism, etc.

Koreans are indeed religious, but more significantly, various religions have coexisted together in an uneasy tension in Korea. A particularly interesting characteristic of Korea's multi-religious tradition is that Eastern religions and Western religions have all maintained a considerable influence on Korean society at the same time. Japan and the United States are also often considered to be multi-religious, yet further investigation reveals that their cases are quite different from that of Korea in a true sense.

In Japan, only Eastern religions such as Shinto and Buddhism are the dominant religions. Furthermore, the multi-religious situation in the United States, which has recently instigated theoretical debate, is strongly founded on Judeo-Christian traditions. Strictly speaking, the conflict between Baptists or Methodists and Catholics in the United States is more a matter of discord between denominations rather than full-blown inter-religious conflicts. Thus, it is clear that the religious situation in Japan and the United States is quite distinct from that of Korea's unprecedented case, which encompasses both Eastern and Western religious traditions without any one particular religion taking precedence over another.

Naturally, a multi-religious situation can create a number of difficulties for any society. Korea cannot be an exception. Above all, Korea's unusual form of multi-religious situation often produces tricky conflicts that would be unimaginable in other countries.

In the latter half of the $20^{\text {th }}$ century, the freedom of religion and the separation of church and state were constitutionally declared in Korea. This meant the actual institutionalization of religious pluralism in Korean society, and conflicts between religions began to be considered in terms of institutional issues. Since there is no longer a state-supported religion and the problems of heresy cannot be raised, interreligious conflicts become inter-organizational issues rather than doctrinal or ritual conflicts.

Furthermore, with the rapid organizational growth of most religions after the 1970s, the multi-religious situation in Korea became a more complicated issue. Once harshly persecuted Catholics became the most powerful religious group in Korea and even invited the Pope to address the painful past of anti-Christian persecution. Protestants, on their part, were able to gather millions of followers together for a revival service at a plaza in Seoul without any public advertisement what so ever. ${ }^{2}$ While Christianity has grown very rapidly in Korea since the $20^{\text {th }}$ century,

1. This Population Census has been acknowledged as the most credible religious population survey because it is most recent statistics that is based on the total population.

2. In March 1984, the New York Times noted that Christianity in Korea had doubled in size during the past 10 years and would double again in the next 10 years. According to the Population Censuses of 1995 and 2005, the number of Catholics increased by 74\%, while 14,000 members of the Korean protestant missionaries were delegated to more than 170 foreign countries in 2005. Currently, there are over 60,000 Christian churches and more than 22,000 Buddhist 
Buddhism and other traditional religions have also gradually worked to modernize their organizations. They have been attempting to redraw the religious power map after the modernization period when Christians dominated the religious landscape.

There has been a reevaluation of Shamanism, which had been ostracized for being a superstition during the modernization period. It is unfortunate that hostility against Shamanism still remains today. A Shaman who prays at Mt. Samgak near Seoul says that she is more afraid of fanatical Protestants who attack shamans than the gods or spirits. Nevertheless, Korean Shamanism is increasingly considered to be an important and basic part of the spirituality of the Korean people.

New religions that have their roots in Korean folk traditions have also been in conflict with fundamental Protestantism, while they are on relatively good terms with Catholicism that has adopted a policy of tolerance towards other religions. This conflict is best exemplified by the debate in the 1980s over the construction of the Tangun (the legendary founder of Korea) sanctuary. Statements were issued from both the new folk religious groups, who supported such construction, and Protestant groups, who were against worshiping Tangun as an ancestor. The issuing of statements caused a great controversy.

It is interesting to note that Protestant opposition to the construction of the Tangun sanctuary by new folk religions has helped Protestants themselves transcend their inter-denominational differences. On the other hand, new folk religions garnered national attention through the mass media and started their own signature-gathering campaigns. This conflict degenerated into physical outbreaks in some places. In a sense, it warned Koreans of the danger of inter-organizational dissension that should be avoided.

But more than any other religion, Buddhism takes the main position among Korea's traditional religions today. Of course, Buddhism is still slow in its revival of lay Buddhist religious life, since for many years its practice has been restricted to remote mountain temples. However, active Buddhist missionary work in urban areas has recently helped to increase the actual influence of Buddhism in Korea. Buddhism has gone beyond its limited historical domain and has increased its social influence enough to speak up in contemporary Korea. Now, it has become impossible for Protestantism to pursue missionary work without taking Buddhism into consideration. In this context, Buddhists have successfully lobbied the government in having the Buddha's birthday recognized as a national holiday.

Both traditional Eastern religions and Western religions have come to claim their respective rights. For example, national events and celebrations often include three ceremonial formalities in contemporary Korea. Namely, Catholic, Protestant and Buddhist ceremonies are usually all performed. In Korea, as is the case with the national funeral ceremonies, one may die once physically, but three times ritually through religious ceremonies of the three religions. It is not uncommon that multiple religious funeral ceremonies are held simultaneously to accord with the different religions of the various family members. This multi-religious culture can also be seen in the religious life in the military and religious activities held in prison.

Naturally, the multi-religious environment can also lead to conflict. There have been incidences of Christians discriminating against Buddhists in the military. There have also been cases of Protestants damaging temple property. Actually, the multi-religious situation of Korea is often referred to as a dormant volcano. Especially, recent conflicts hint at the possibility of irrecoverable calamities. Such conflicts between religions can cause social problems and eventually develop into a national social disaster.

As expected, such religious conflicts have also developed into the field of education in contemporary Korea. First, there have often been controversies about a strict enforcement of religious education in parochial schools. In addition, there has been much controversy over the excessive doctrinal propaganda in Christian schools. In a recent incident, a certain Christian high school student named Kang Uiseok refused to attend a forced chapel and went on a hunger strike demanding religious freedom. As a result, he was expelled from the school after which he filed a lawsuit against the school board.

On the other hand, Protestants themselves have asserted that the idea of "devotion to the welfare of mankind (Hongikingan)", derived from the legendary national founder, Tangun, as advocated in the Korean Education Law (presently titled Basic Law of Education) was not based upon historical facts and was influenced by chauvinistic and biased views of a particular new folk religion. These Protestants, instead, have argued that there should be more emphasis placed on the idea of democracy. However, most of new folk religious groups have refuted Protestants' assertion by appealing to the idea of a national spirit.

In 1984, Buddhists criticized the Christian-centered bias of national moral education textbooks used in Korean

temples in Korea. It goes without saying that the Yoyuido Full Gospel Church in Seoul is still the biggest Christian church in the world having the largest number of members and several Korean churches are included among the world's 20 largest churches. 
high schools and colleges. And Buddhists have questioned whether Christianity should be taught as part of the national moral education like traditional Eastern religions. This may seem to be a mere academic dispute, but the controversy over the textbooks reminded Buddhists of their contemporary situation of anti-Buddhist persecution.

In 1990s, a new folk religious group founded on a special method of meditation and breathing campaigned for the construction of Tangun statute in elementary schools nationwide and the Protestants strongly opposed it. The new folk religious group argued that it was not for religious worship but as an act of basic respect for the legendary national founder. The Protestants responded by denouncing that the campaign was a religious exercise of propaganda by a particular religious body and a clear violation of the constitution.

It is needless to continue with more examples. There have continually been serious religious conflicts in Korea. It is well known that most religions have emphasized peace and love. Yet, in fact, they have been the core source of social conflicts in Korea. There are many reasons for such religious conflicts, but ignorance of each other is likely to be the most fundamental cause. How could Protestants cut off the heads of traditional Korean 'totem' poles (Jangseung), which have long been the symbols of tutelary deities in villages, if they knew the true meaning behind these spiritually deep-rooted traditions? How could it happen that fanatical Protestants beheaded the statues of the Buddha with axes or drew the sign of the cross on the foreheads of the Buddha statues, if they knew? All miseries have basically originated from mutual ignorance.

It is critically significant that religions should firstly know about other religions in order to avoid such conflicts. If they know about other religions, many conflicts will be reasonably overcome. Of course, it is one way of knowing indirectly about other religions to read books about them and to refer to audio-visual materials of them. However, it is more desirable for religious people to meet each other directly and talk to each other frankly.

Accordingly, it is said that interreligious dialogues have been emphasized in case of religious conflicts. Once they meet and talk, religious groups will come to understand each other. Once they understand each other, they will also come to understand how valuable each religion is to the respective groups. If religions could be understood to be valuable to each other, there would no longer exist conflicts between them. It is in this context that interreligious dialogues should be noted in contemporary multi-religious situation.

Up to now, most interreligious dialogues have not been successful as expected, mainly because they are just occasionally and held between only religious leaders. In this sense, religious education might be one of the most effective interreligious dialogues today. Students as laypeople can have a chance to regularly meet and talk together directly and widely through religious education. In particular, the recent regularization of "religion" curriculum in official education would be very productive in terms of such an interreligious dialogue against religious conflicts in contemporary Korea. Now, let me introduce the basic structure of Korean religious education, before I explain the Korean heuristic case.

\section{Structure of Korean Religious Education}

Modern education is sharply distinguished from the traditional education in the history of Korean education. Traditional education in Korean society was mainly developed on the basis of both Buddhism and Confucianism. Accordingly, there was no strict separation between secular education and religious education and thus, in a sense, the secular was undifferentiated from the religious in the domain of education. For example, Seowon, which was one of the representative private schools in traditional Korea, served not only as an academic lecture hall but also as a memorial hall for the great Confucian scholars and loyal subjects of the past.

It was not until the end of $19^{\text {th }}$ century when Protestantism was transmitted and Western style schools were established that modern education began to separate from religion. In 1884, the government officially declared the adoption of the modern educational system. Then elementary schools appeared and Western style middle and high schools followed. As the modern Korean educational system emerged, education came to occupy its own autonomous position distinguished from religion.

Of course, traditional education was not immediately overwhelmed by the modern education and had not completely disappeared after the start of the modernization of education in Korea. Modern education partially included religious education as well as purely secular education. Some part of traditional Confucian education still continues with the teaching of Chinese characters, though it has been changed much. The traditional Buddhist education has also been uniquely transformed and kept up in temples. But they belong to a kind of non-official (religious) education managed by the educational institutions of the particular religious bodies themselves. Christian seminaries might also be considered in a similar context, even if the government officially accredits some of them like secular colleges. 
As modern education came to be separated from the religious domain and formed an autonomous domain, official (secular) schools emerged as centers of official education. Modern schools came to provide a curriculum that was divided into specialized topics, such as mathematics, science, foreign languages, etc., which were very different from the undifferentiated curriculum of the traditional schools. Nevertheless, this does not mean that the religious contents of the traditional education become meaningless. Thus, the modern secular education includes a lot of religious contents in its non-religious courses like 'history,' 'ethics,' 'society,' etc. Furthermore, official (secular) schools established by religious orders have taught religion with a special emphasis on their goals of mission and self-cultivation.

TABLE I: Religious Education and Secular Education in Korea

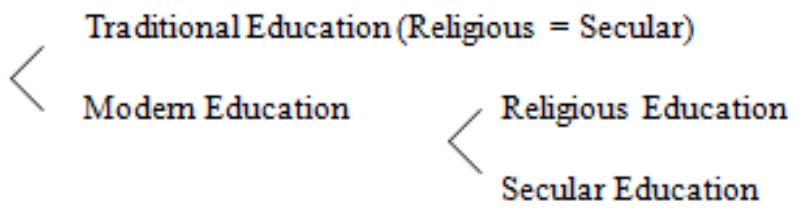

According to the current Korean Constitution, "All the people should have the freedom of religion. The Establishment should not be allowed and religion should be separated from the state." (Article 20) The so-called principles of 'religious freedom' and 'No Establishment (the separation of church \& state)' are codified in Korea as in most modern countries. Related to the provision of No Establishment, the Korean Basic Law of Education stipulates that "the public schools established by the state or the local self-government should not give religious education for a particular religion."'(Article 6$)$

Strictly speaking, the notion of "religious education for a particular religion" in the Basic Law of Education means education as a part of religious activities like proselytism. In other words, it does not matter that they teach religion as a part of human cultural phenomena or a social institution on academic or humanistic dimensions. The education of religion as the object of academic inquiry is not a problem. Accordingly, current curricula of 'society' and 'morals' in elementary and middle schools and those of 'history,' 'ethics,' 'society and culture,' etc. in high schools contain a considerable portion related to particular religions. However, religious contents in such a secular curriculum are not intended to understand religion itself and they deal away with religion in their own way. Thus, understanding religions is not very systematic and just fragmentary. Textbooks are often biased and incorrect, because scholars of religion did not write them.

On the other hand, the mainline institutions of religious education in Korea are naturally religiously established (private) schools. They are usually officially certified educational institutions that are established and mostly managed by religious bodies. The number of the religiously established schools from elementary schools to colleges is about 400 in Korea today. There are about 20 Buddhist-established middle and high schools and a little more than 270 Christian-established middle and high schools among them. The number of such religiously established schools amounts to the $10 \%$ of all the middle and high schools.

The religiously established middle and high schools are official educational institutions accredited by the government and thus they also offer a secular curriculum, as is the case with non-religiously established schools as well as public schools. But, at the same time, they usually impose the attendance of regular worship services like chapels and more than one hour of religious curriculum on their students weekly, since they were originally established to realize religious goals.

TABLE II: Cotemporary Korean School System in Relation to Religion

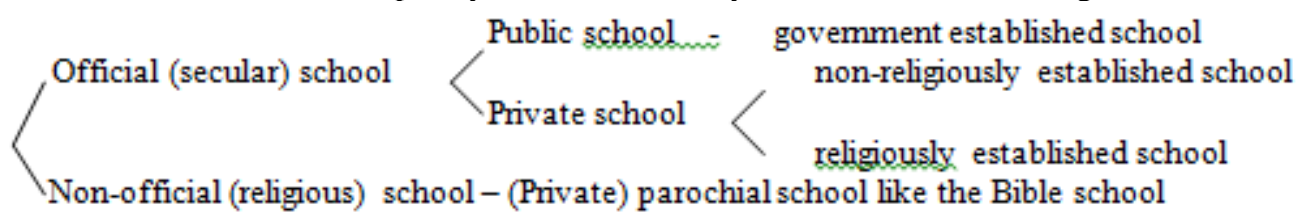

Here, it should be noted that religiously established middle and high schools had individually managed the religious curriculum in their own ways until 1970s: courses were offered as "the Bible" for the Christianestablished middle and high schools and as "Buddhism" for the Buddhist-established middle and high schools. In other words, these religiously established schools had not offered religious courses as a regular curriculum but as an irregular (non-credit) curriculum. Naturally, this presented contradictions and difficult situations in religiously 
established schools.

For example, teachers for religious courses could not get a teacher's certificate accredited by the government and thus they had to be employed as a supporting staff and not regular teachers. As a result, they could not enjoy the same rights as regular teachers in terms of their status, pension and etc. Students also used to neglect religious courses, because they spent more time in other regular courses.

In this context, it is noteworthy that Korean Ministry of Education should include 'religion' courses into the regular accredited curriculum of official education in 1982. This was the regularization of religious curriculum in Korean middle and high schools. That is, in order to remedy the limping actualities of religiously established schools, the regularization was initiated at the request of the religiously established schools themselves and was not at all the result of soliciting by the state or the educational communities. But this regularization was expansively implemented in all the middle and high schools in Korea on the pretext of self-cultivation and humanistic liberal education for students. In effect, religious education became a part of official education in contemporary Korea through the regularization of religious curriculum in middle and high schools.

\section{Regularization of Religious Curriculum and Interreligious Dialogue}

For the first time, in the modern history of Korean education, "religion" as a regular course in an official education was enacted as an elective course with other courses such as "philosophy," "logic," "psychology" and "education" as outlined in the $4^{\text {th }}$ Curricula for High School. (1982-1988, Ministry of Education 442) Above all, it is important that this regularization applies to all the high school students as well as the students of religiously established schools in Korea. That is, not only religiously established schools but also all the high schools including public schools and non-religiously established private schools have come to be able to offer "religion" as a regular elective curriculum. Strictly speaking, if a certain school offered "religion" as an elective curriculum, it is stipulated that the school has only to offer students one other elective course, in order to give the students a choice to not take "religion".

In the meantime, the Curricula for High School has continually changed every five years and the $7^{\text {th }}$ Curricula for High School (2002-2007) is enacted now. However, related to religious curriculum, the Curricula for High School has made just minor revisions. Middle and high schools have come to offer these elective courses including "religion" for 1 to 4 hours in a week.

In other words, the regularization of religious curriculum as an elective course (firstly indicated in the $4^{\text {th }}$ Curricula for High School) does not mean that the curriculum was newly created for religiously established middle and high schools. Rather, significance lies in the fact that the old courses taught as "the Bible" or "Buddhism" has come to be regularized into elective courses.

However, such regularization of religious courses in religiously established schools also meant that they gave up previous autonomous and even arbitrary curriculum and had to certify the characteristics of the curriculum as part of the official education. It was not until the $6^{\text {th }}$ Curricula for High School (1995-2001) that the concrete contents and framework of "religion" curriculum were formed. It was not an easy task to formulate the contents, because a standardized common "religion" curriculum had to be developed for all the students including even non-religious students of non-religious public schools. This meant a resolute academic generalization of the stereotyped dogmatic teachings, practices and church histories that the religiously established schools had taught just for their own religion. Naturally, the new curriculum put more emphasis on the contents about general theories and cultural traditions of religions. However, the old mission-oriented trends of religiously established schools that had played a leading role for the regularization of the "religion" curriculum could not be very easily discarded at once. Thus, it still being a transitional period, the two aspects of the situation had to be eclectically reflected. The new content of the "religion" curriculum was developed as follows.

The framework of the contents consists of 6 sections, among which the sections 1, 4 and 5 fell into general theories of religion and sections 2 and 3 were related to the religious traditions. Section 6 was arranged in order to accommodate for the already existing religious knowledge of the religiously established schools. It might be said that the two sides of the religious education, namely official education and parochial education, were pragmatically negotiated. The compromise of the two ideas has also been regarded as the core issue of the "religion" curriculum for middle and high schools in Korea until now. 


\begin{tabular}{|c|c|}
\hline Sections & Contents \\
\hline \multirow[t]{4}{*}{ 1. Human and Religion } & Religions in People's Life \\
\hline & Believing and Understanding \\
\hline & Encounter with the Ultimate Reality \\
\hline & Formation of the Religious Personality \\
\hline \multirow[t]{3}{*}{ 2. World Culture and Religion } & Traditions and Thoughts of Hinduism, \\
\hline & Buddhism, Confucianism, Taoism, Christianity, \\
\hline & Islam and the Other Religions \\
\hline \multirow[t]{3}{*}{ 3. Korean Culture and Religion } & Korean Folk Beliefs, New Religions \\
\hline & The Acculturation of Buddhism, Confucianism, \\
\hline & Taoism, Christianity and Islam \\
\hline 4. Understanding of Religious & Perspectives of Faith, Rituals and Religious Practices \\
\hline Experiences & Religious Community \\
\hline \multirow[t]{3}{*}{ 5. Modern Society and Religion } & Modern Meaning of the Sacred Literature \\
\hline & Religion Confronting Secular Culture, \\
\hline & Interreligious Dialogue, Religion and Ideal Society \\
\hline \multirow{3}{*}{$\begin{array}{l}\text { 6. Teachings and History of } \\
\text { a Particular Religion }\end{array}$} & Cannon of the Religion, Teachings of the Religion \\
\hline & Religion in Daily Practices \\
\hline & Religion and Future in Korea \\
\hline
\end{tabular}

The two ends within the "religion" curriculum are also harmoniously maintained in the current $7^{\text {th }}$ Curricula for High School (2002-2007), even despite reoccurring intense confrontations. Nevertheless, it can be said that the academic demand has gradually strengthened, while the mission-oriented tendencies have weakened.

Above all, it is significant that scholars, teachers and even administrators and staffs of education from different religious backgrounds have come together to create a "religion" curriculum. There has not been any chance for them to talk to each other and to come to know other religions before. But through this process they came to realize the significance of the unique multi-religious situation in Korea. There was a mutual agreement that the "religion" course as part of the official education should stand in the vanguard of overcoming religious conflicts in Korea. It has been re-emphasized that students should learn about other religions and develop their ability to understand it through the "religion" curriculum.

The "religion" textbooks written on the basis of the curriculum should follow official procedures imposed by the Ministry of Education in order to become "authorized textbooks". The actual authorization is a matter under the jurisdiction of the Local Office of Education. The Local Office of Education usually entrusts professors of religious studies and high school teachers from different religious background with examining authorization. Referring to their evaluation, the Local Office of Education then exercises its right of authorization.

The most important in the authorization procedure of textbooks is to indicate the factual mistakes of the contents and, furthermore, to judge and correct slanderous or distorted descriptions against other religions. During the examination of authorization, professors of religious studies and teachers who are monks, nuns and ministers usually meet each other for the first time and iron out conflicting religious views for a sound religious education. Because these procedures are opened to the public, scholars from other religions are often invited to write sections about different religions. In the meantime, it could be said that a "practical" interreligious dialogue happens on a deep dimension.

As "religion" curriculum was officially regularized, the teachers of religion courses have experienced a big change in their official status. For the first time, they obtained a teachers' certificate accredited by the state and their status has come to be legally guaranteed. They became a regular teacher in its true sense: they were no longer different from the teachers of other courses such as mathematics or science and not just a supporting staff. It meant that a regular teaching credential for "religion" was needed in order to be a teacher of a "religion" course, differently from how such teachers were informally recommended by the religious schools like seminaries or Buddhist colleges previously. This means that a candidate for a "religion" teacher should complete a fixed number of courses related to religious studies and education. Most seminaries and departments related to theology, Buddhist studies as well as religious studies should offer required courses for a "religion" teaching credentials and also recruit new faculty members to teach such courses for future teachers. Naturally, concerns about other religions and religious studies have increased through new lectures, seminars, symposiums and etc. in the seminaries and departments of colleges and universities.

However, in the beginning, all the existing parochial teachers without "religion" teaching credentials could not suddenly be dismissed and be replaced by new certificated teachers. Thus a year-long temporary intensive retraining courses have been prepared for the current teachers on several occasions through which hundreds of 
existing teachers were endowed with a certificate.

Here, it may be noted that profound interreligious dialogues also occurred in the retraining courses. Let's imagine a class with teacher-students who are Buddhist monks, Catholic nuns and Protestant ministers discussing the sacred and the profane, Freud and the Oedipus myth, African initiation rites and totemic symbols. There is no longer a monologue by one's own religion. Everything is discussed on the level of interreligious dialogues. The retraining courses usually include fieldtrips with chances to have a live-in experience in the womb of another religion. Catholic nuns and Protestant ministers were able to participate in early morning Buddhist prayers with Buddhist monks and listen to a live voice explanation of the Buddha statute's true meaning for Buddhists. The monks were able to see ritualistic similarity between Christian prayer and Zen. In those moments, all of them came to a collective consciousness and became one. The retraining course is a kind of initiatory process for the old parochial teachers to be born again as a regular "religion" schoolteacher. They experience the one communitas in the name of a "religion" teacher to be accredited by the state.

Furthermore, let's imagine the "religion" class for middle and high school students that the teachers teach on the basis of their inter-religious experiences. At least, the students can come to encounter the "other name" for the unknown God and ask the teachers easily, "Why do Christians seek an invisible God?" or "Why do Buddhists pray to a stone Buddha statute with their hands pressed together?" Then they can afford to admit, "How wrong they were to have misunderstood and thought of the other as an idol worshipper!" and "How badly they have hurt each other!" At last, changed teachers can change students. In turn, changed students can also change the future of a society.

\section{Issues and Prospects of Official Religious Education in Korea}

Of course, it cannot be said that religious education as an official education has been successful enough in contemporary Korea. There are still a lot to be desired. We should be reminded of the fact that the regularization of "religion" curriculum was not intended for only the students of religiously established schools, but for all the Korean middle and high school students. That is, the real issue was whether the regularization could also be applicable to the students of public schools and non-religious private schools. But there has so far been no case of non-religious schools offering the "religion" course as their regular elective curriculum.

If a school is actually to offer a "religion" course as an elective, the school has to offer another elective course besides the "religion" course and give students room for choice, as it was mentioned above. That is also why (public or private) non-religiously established schools do not offer a "religion" course: they are burdened with employing another teacher and forming another class. Another reason is the fact that there is still no "religion" textbook free of any particular religious background.

On the other hand, there has been no religiously established school that has not offered a "religion" course. Furthermore, the religiously established schools offer only a "religion" course as a regular elective curriculum and not any other elective course for students' choice. They have justified this by making a poor excuse that there are not enough students to take other elective courses. Therefore, it seems true that a "religion" course is legally the regular elective curriculum for the general education of the middle and high schools, but actually it has indeed become a very special curriculum to be taught only in religiously established schools in Korea these days.

Moreover, it should be noted that students are usually allocated to their middle and high schools by means of a computer drawing system in Korea today. Accordingly, a non-religious student can be allocated to a religiously established school, while a religious student is often allocated to a non-religious school. Even a Buddhist student has been reluctantly allocated to a Protestant school and a Catholic student to a Buddhist school. It must be unconstitutional to forcibly send students to a school that does not fit their religious disposition. Of course, a student is usually allowed to be absent from the "religion" class and other religious activities, if he is insistent on not attending. However, it is indeed not easy for such a student to resist and still attend school.

In this context, it is said that the "religion" curriculum should go beyond the old parochial mission-oriented tendency and toward a new academic, self-cultivating and humanistic direction in the future, even if gradually. That is, the "religion" course in middle and high schools should be helpful for educating students to have a sound religious sense to have the students understand the contemporary Korean multi-religious situation and to help them to live harmoniously in it. The first step now would be to create a non-parochial "religion" textbook, which could be used in non-religiously established schools.

In fact, religion tends to be contrasted with scientific knowledge and thus has been excluded from academic subjects for official education since the beginning of the modernization in Korea. But the official religious 
education through the regular "religion" curriculum is thought to have played a very important role in overcoming conflicts caused by religious prejudices. In this sense, the definite social need and the usefulness of an official religious education seems to have been increasingly acknowledged.

We might realize that if there is too much dynamics bringing about conflict in a multi-religious society, official religious education can be a good soothing mechanism. The regularization of religion curriculum can be, above all, said to be one of the most effective embodiments of such religious educational efforts, because it invites various kinds of dimensions for interfaith dialogues. At least, the Korean case may be heuristic and also suggest a creative model for the other countries that are struggling with religious conflicts today. 